\section{PEMILIHAN LOKASI TERBAIK PENGEMBANGAN PROPERTI APARTEMEN DI PERKOTAAN CIBINONG RAYA KABUPATEN BOGOR}

\author{
Jurnal Pengembangan Kota (2017) \\ Volume 5 No. 1 (93-103) \\ Tersedia online di: \\ http://ejournal2.undip.ac.id/index.php/jpk \\ DOI: $10.14710 / j p k \cdot 5.1 .93-103$
}

\author{
Muhammad Saifuddin Amanullah*, Ragil Haryanto \\ Departemen Perencanaan Wilayah dan Kota \\ Fakultas Teknik Universitas Diponegoro
}

\begin{abstract}
Abstrak. Sebagai salah satu penyangga ibukota DKI Jakarta, Perkotaan Cibinong Raya menjadi salah satu lokasi tujuan untuk bertempat tinggal. Pertumbuhan penduduk Perkotaan Cibinong Raya mengalami peningkatan sebesar 16,37\% (BPS Kabupaten Bogor, 2016), yang kemudian diikuti dengan peningkatan permintaan akan hunian tempat tinggal. Di sisi lain, ketersediaan lahan di Perkotaan Cibinong Raya luasnya semakin terbatas sehingga diperlukan optimalisasi penggunaan lahan agar mencapai nilai yang optimum. Tujuan dari penelitian ini yaitu untuk menentukan lokasi terbaik pengembangan properti apartemen di Perkotaan Cibinong Raya. Hasil penelitian ini diharapkan dapat menghasilkan perspektif yang berbeda dengan yang digunakan oleh para pelaku pengembang property dengan menggunakan variable-variable yang disarikan dari kajian literature yang terkait. Penelitian ini menggunakan metode pendekatan kuantitatif dengan teknik analisis Analytical Hierarchy Process (AHP) dengan para ahli terkait pengembangan property sebagai penilai/responden. Hasil dari penelitian ini yaitu terdapat empat lokasi alternatif yang layak untuk dikembangkan sebagai lokasi properti apartemen. Keempat lokasi alternatif tersebut kemudian disebut sebagai Lokasi A, Lokasi B, Lokasi C dan Lokasi D. Berdasarkan hasil AHP, didapati lokasi yang memiliki nilai tertinggi dan sebagai lokasi terbaik pengembangan properti apartemen secara berturut-turut yaitu Lokasi $D(0,336)$, Lokasi $A$ $(0,309)$, Lokasi C $(0,218)$ dan Lokasi B $(0,139)$.
\end{abstract}

Kata kunci: lokasi terbaik; Highest and Best Use (HBU); apartemen; Cibinong Kabupaten Bogor

[Title: The Best Location for Property Apartment Development in Cibinong Urban Area, Bogor Regency]. As a part of Greater DKI Jakarta or known as Jabodetabek, Cibinong Raya offers alternatives for residence location. The statistic of population in Cibinong noted that its population has grown by $16.37 \%$ (BPS Bogor Regency, 2016) that has implication on the increase of residential dwelling demand. However, the amount of non-built area in the city is limited. So, land use optimazition strategy is significant to reach the optimum land-use value. The result of this study is expected to give different perpective of property development applied by the property developers in Indonesia. Hence, this research applied variables derived from the literature reviews and asked the property experts to analyse the variables. Using Analytical Hierarchy Process (AHP), it was revealed that there were four suitable alternative location named as Location A, Location $B$, Location C and Location $D$. Based on the experts perception through AHP method, the study showed that the highest optimum value was Location $D(0.336)$ and followed by Location A (0.309), Location C (0.218) and Location B (0.139).

Keyword: best location; Highest and Best Use (HBU); apartment; Cibinong Bogor Regency

CaraMengutip: Amanullah, M S., Haryanto, R (2017). Pemilihan Lokasi Terbaik Pengembangan Properti Apartemen di Perkotaan Cibinong Raya Kabupaten Bogor. Jurnal Pengembangan Kota. Vol 5 (1): 93-101. DOI: 10.14710/jpk.5.1.93-101

\section{PENDAHULUAN}

Kawasan Jabodetabek merupakan salah satu kawasan yang mengalami pembangunan dan pengembangan lahan paling masif di Indonesia (Winarso \& Firman, 2002). Fenomena pembangunan dan pengembangan lahan di Jabodetabek ini tidak terlepas dari tingginya laju pertumbuhan penduduk akibat dari urbanisasi di kawasan perkotaan Jabodetabek. Besarnya proporsi penduduk yang berada di kawasan perkotaan, menjadi indikasi awal dari tinginya

ISSN 2337-7062 (Print), 2503-0361 (Online) @ 2017

This is an open access article under the CC-BY-NC-ND license (http://creativecommons.org/licenses/by-nc-sa/4.0/). - lihat halaman depan (c) 2017

*email: aifmsa.pwkundip@gmail.com Telp. +6285770969562

Diterima 7 Januari 2017, disetujui 2 Juli 2017 
tingkat pembangunan suatu negara (Pontoh \& Kustiwan, 2009).

Peraturan Daerah Kabupaten Bogor Nomor 19 Tahun 2008 tentang Rencana Tata Ruang dan Wilayah Kabupaten Bogor menempatkan Perkotaan Cibinong Raya termasuk ke dalam orde I Kabupaten Bogor dimana memiliki aksesibilitas tinggi terhadap Pusat Kegiatan Nasional (PKN) Jakarta Bogor Depok Tangerang Bekasi Puncak dan Cianjur atau yang dikenal sebagai Jabodetabekpunjur. Kemudahan dan tingginya tingkat aksesibilitas mendorong penduduk yang bertempat tinggal diluar kawasan Perkotaan Cibinong Raya tertarik untuk tinggal dan menetap di kawasan Perkotaan Cibinong Raya. Seiring dengan bertambahnya jumlah penduduk, kebutuhan lahan akan hunian tempat tinggalpun jumlahnya semakin meningkat.

Di sisi lain, luas lahan non terbangun di Perkotaan Cibinong Raya hanya menyisakan $26,16 \%$ dari luas total wilayah administrasi Perkotaan Cibinong Raya (Bappeda Kabupaten Bogor, 2016). Adanya ketimpangan antara permintaan lahan untuk hunian tempat tinggal yang semakin meningkat dengan ketersediaan lahan yang semakin berkurang, menjadikan tantangan baru bagi Perkotaan Cibinong Raya. Pengoptimalisasiaan penggunaan lahan perlu dilakukan di Perkotaan Cibinong Raya karena lahan seringkali dipandang sebagai suatu aset produktif yang dapat membangkitkan dan meningkatkan kegiatan investasi (Chavunduka \& Bromley, 2013), serta memberikan dampak terhadap pola dan harga bangunan ( $\mathrm{Du}, \mathrm{Ma}, \& \mathrm{An}, 2011)$. Hal ini tentunya tidak terlepas dari karakteristik lahan yang merupakan kebutuhan mutlak manusia serta mempunyai sifat yang unik apabila dibandingkan dengan aspek-aspek lain yang dibutuhkan untuk kehidupan manusia (Sadyohutomo, 2008).

Sebagai respon dari fenomena tersebut, Pemerintah Daerah Kabupaten Bogor menerbitkan Perda no 19 Tahun 2008 tentang Tata Ruang Wilayah Kabupaten Bogor dimana salah satunya mengatur mengenai pengembangan properti untuk hunian tempat tinggal di kawasan Perkotaan Cibinong diarahkan kepada jenis bangunan vertikal. Di daerah perkotaan dimana tingkat kebutuhan ruang yang sangat tinggi, pengembangan hunian dengan konsep hunian tapak menjadi kurang efisien (Logan, Bian, \& Bian, 1999). Konsep hunian vertikal merupakan salah satu cara meminimalisir penggunaan lahan agar dapat memperbanyak ruang-ruang terbuka di perkotaan (Hirsch, 1977).

Adanya fenomena dan paradigma baru dalam penyediaan hunian di Perkotaan Cibinong Raya saat ini, menjadi suatu hal yang menarik untuk dijadikan sebuah penelitian mengenai pemilihan lokasi terbaik dalam pengembangan properti apartemen di Perkotaan Cibinong Raya. Oleh karena itu, penelitian ini bertujuan untuk mengkaji alternative terbaik untuk pemilihan lokasi pengembangan property apartemen di Perkotaan Cibinong Raya. Studi ini perlukan untuk memberikan perspektif terkait dengan pengembangan property di Indonesia yang berbeda mungkin berbeda dengan yang dipergunakan oleh para pengembang property selama ini. Selain itu hasil penelitian ini diharapkan dapat menjadi masukan bagi pemerintah daerah dalam menentukan kebijakan terkait zoning permukiman dalam perencanaan kota, sebagaimana yang dilakukan di beberapa negara bagian di Amerika Serikat (Magliocca, McConnell, Walls, \& Safirova, 2012; Qian, 2010).

Terkait dengan pemilihan lokasi dalam pengembanga property, terdapat tiga kriteria lokasi alternatif yang meliputi guna lahan eksisting, peruntukan kawasan (Kuswara, 2004) dan pencapaian ke pusat kota (Fajar, Sarjono, \& Iswanto, 2016). Selain ketiga kriteria lokasi alternatif pengembangan properti, juga terdapat tiga kriteria pemilihan lokasi terbaik pengembangan properti apartemen. Ketiga kriteria tersebut terdiri dari kriteria legalitas, kriteria fisik dan kriteria ekonomi (Appraisal Institute, 2001). Adapun delapan sub kriteria dari masing-masing kriteria tersebut yaitu sub kriteria fisik terdiri dari aksesibilitas (Chang, Liao, Tseng, \& Liao, 2015), moda transportasi (Koester, 2001) serta sarana dan prasarana. Sub kriteria legalitas terdiri dari peruntukan kawasan (Kuswara, 2004), kepemilikan lahan (Al-Ossmi \& Ahmed, 2016; Morrow-Jones, Irwin, \& Roe, 2004) dan regulasi hunian vertikal (Kombaitan, 1995). Sedangkan sub kriteria ekonomi terdiri dari harga lahan (Kheir \& Portnov, 2016) dan pasar (Kuswara, 2004). Kriteria dan sub kriteria 
pemilihan lokasi terbaik pengembangan properti apartemen dapat dilihat pada Tabel 1 berikut:

Tabel 1. Kriteria dan Sub Kriteria Pemilihan Lokasi Terbaik Pengembangan Properti Apartemen

\begin{tabular}{ll}
\hline \multicolumn{1}{c}{ Kriteria } & \multicolumn{1}{c}{ Sub Kriteria } \\
\hline \multirow{3}{*}{ Fisik } & Aksesibilitas \\
\cline { 2 - 2 } & Moda transportasi \\
\cline { 2 - 2 } Legalitas & Sarana dan prasarana \\
\cline { 2 - 2 } & Peruntukan kawasan \\
\cline { 2 - 2 } Ekemomilikan lahan \\
\hline \multirow{2}{*}{ Regulasi hunian vertikal } \\
\hline
\end{tabular}

\section{METODE PENELITIAN}

Penelitian ini menggunakan metode pendekatan kuantitatif dengan teknik analisis weighted overlay dan teknik analisis Analytic Hierarchy Proccess (AHP). Teknik analisis weighted overlay merupakan teknik analisis keruangan yang memadukan beberapa jenis peta secara tumpang tindih dengan bantuan perangkat lunak Geographic Information System (GIS) (Karana \& Suprihardjo, 2013). Pada penelitian ini, teknik analisis weighted overlay digunakan untuk menganalisis lokasi alternatif pengembangan properti apartemen di Perkotaan Cibinong Raya Kabupaten Bogor.

Selain teknik analisis weighted overlay, penelitian ini juga menggunakan teknik analisis Analytic Hierarchy Proccess (AHP). Menurut Saaty (1993), AHP adalah sebuah kerangka untuk mengambil keputusan dengan efektif atas persoalan yang kompleks dengan menyederhanakan dan mempercepat proses pengambilan keputusan dengan memecahkan persoalan tersebut. Pengolahan data yang dilakukan dengan menggunakan teknik analisis AHP diawali dengan pengidentifikasian yang kemudian dilakuan penetapan perspektif kriteria yang disesuaikan dengan kebutuhan dalam pemilihan lokasi terbaik pengembangan property apartemen. Data diperoleh dengan cara memberikan kuesioner kepada para ahli yang kemudian, data-data tersebut diolah dengan menggunakan software Expert Choice. Output dari pengolahan data dengan menggunakan teknik analisis AHP ini berupa angka bobot hasil perbandingan tiap-tiap kriteria, sub kriteria dan alternative. Untuk mengukur tingkat validitas hasil dari pengolahan data tersebut, dapat dilihat dari besaran nilai indeks konsistensi. Menurut Saaty (1993), suatu data dikatakan valid apabila memiliki nilai indeks konsistensi kurang dari 0,1 atau $10 \%$. Pada penelitian ini, teknik analisis AHP digunakan untuk menganalisis pemilihan lokasi terbaik pengembangan properti apartemen berdasarkan persepsi dari para ahli terhadap beberapa lokasi alternatif yang dihasilkan dari analisis weighted overlay.

Teknik sampling yang digunakan dalam penelitian ini yaitu non probability sampling dengan metode purposive sampling, dimana pemilihan sampel tidak dilakukan secara acak, sehingga tidak semua anggota populasi memiliki peluang yang sama (Sugiyono, 2014). Pada penelitian ini, jumlah sampel sebanyak delapan responden yang terdiri dari beberapa ahli dengan latar belakang sebagai instansi pemerintahan, swasta, serta akademisi, yang dianggap representatif dengan penelitian ini.

\section{HASIL DAN PEMBAHASAN}

Identifikasi Kriteria Lokasi Alternatif Pengembagan Properti Apartemen. Identifikasi kriteria lokasi alternatif pengembagan properti apartemen ini terdiri dari 3 (tiga) kriteria yang berpengaruh dalam pemilihan lokasi alternatif pengembangan properti apartemen. Kriteria-kriteria tersebut meliputi kriteria guna lahan (landuse) eksisting, regulasi peruntukan kawasan, serta jangkauan pencapaian ke pusat kota.

Guna lahan eksisiting di Perkotaan Cibinong Raya didominasi oleh guna lahan permukiman seluas $5.016 \mathrm{Ha}$ atau sebesar $66.4 \%$ dari luas total administrasi Perkotaan Cibinong Raya. Menurut Kuswara (2004), jenis pengembangan lokasi hunian baru merupakan lokasi hunian yang dikembangkan pada lahan non-terbangun. Jenis lokasi hunian pengembangan baru ini cocok diterapkan untuk pengembangan hunian bertingkat mengingat secara pengembangannya lebih mudah dan lebih efisien dari pelaksanaan dan pembiayaannya. Namun, tidak semua lahan non terbangun dapat dijadikan lokasi pengembangan hunian baru. 
Peraturan Menteri Pekejaan Umum Nomor 41 Tahun 2008 mengatur mengenai kriteria-kriteria lokasi pengembangan hunian diantaranya lokasi pengembangan hunian menghindari penggunaan lahan sawah teknis, kawasan lindung, serta tidak berada pada wilayah semapadan sungai/ pantai/ waduk/ danau/ mata air/ saluran pengairan/ rel kereta api dan daerah aman penerbangan.

Sejalan dengan kriteria-kriteria yang dikeluarkan oleh Kementerian Pekerjaan Umum (Nugraha, Nugraha, \& Wijaya, 2014) dalam jurnalnya yang berjudul Pemanfaatan SIG untuk Menentukan Lokasi Potensial Pengembangan Kawasan dan Permukiman, mengkategorikan skoring guna lahan menjadi tiga kelas skor yaitu sesuai, kurang sesuai dan tidak sesuai. Guna lahan tegalan merupakan jenis guna lahan yang dianggap paling sesuai. Pada kategori kedua, terdapat guna lahan berupa sawah tadah hujan dan perkebunan yang dinilai kurang sesuai. Sedangkan Sawah irigasi, hutan, sungai dan perairan merupakan jenis guna lahan yang paling tidak sesuai untuk pengembangan lokasi hunian. Selain ketiga paparan di atas, penyusun juga melakukan wawancara dengan pihak Bappeda Kabupaten Bogor untuk menentukan skor penilaian terhadap masing-masing jenis guna lahan untuk pengembangan lokasi hunian apartemen. Skoring guna lahan dapat dilihat pada Tabel 2 berikut:

Tabel 2. Skoring Guna Lahan

\begin{tabular}{lcc}
\hline \multicolumn{1}{c}{ Guna Lahan } & Skor & \multicolumn{1}{c}{ Sumber } \\
\hline $\begin{array}{l}\text { Sempadang } \\
\text { Sungai }\end{array}$ & 3 & Permen PU No. 41/ 2008 \\
\hline Belukar/ semak & 1 & Bappeda Kab. Bogor \\
\hline Hutan Lebat & 3 & Nugraha, dkk (2014) \\
\hline Industri & 3 & Kuswara (2004) \\
\hline Lahan terbuka & 1 & Bappeda Kab. Bogor \\
\hline Perairan darat & 3 & Nugraha, dkk (2014) \\
\hline Perkebunan & 2 & Nugraha, dkk (2014) \\
\hline Permukiman & 3 & Kuswara (2004) \\
\hline Sawah Irigasi & 3 & Permen PU No. 41/ 2008 \\
\hline $\begin{array}{l}\text { Sawah tadah } \\
\text { hujan }\end{array}$ & 2 & Nugraha, dkk (2014) \\
\hline Setu & 3 & Nugraha, dkk (2014) \\
\hline Sungai & 3 & Nugraha, dkk (2014) \\
\hline Tegalan & 1 & Nugraha, dkk (2014) \\
\hline Keterangan : & 1: Sesuai & \\
& 2: Kurang Sesuai & \\
\hline : Tidak Sesuai &
\end{tabular}

Peruntukan kawasan merupakan salah satu kriteria penting dalam pemilihan lokasi alternatif pengembangan properti apartemen. Menurut Logan, dkk. (1999) di daerah perkotaan dimana tingkat kebutuhan ruang yang sangat tinggi, pengembangan hunian dengan konsep hunian tapak menjadi kurang efisien. Konsep hunian vertikal merupakan salah satu cara meminimalisir penggunaan lahan di daerah perkotaan (Hirsch, 1977). Selain di pusat perkotaan (Akmal, 2007) menyarankan untuk pemilihan lokasi apartemen dilalui oleh jaringan transportasi umum agar memberikan kemudahan penjangkauan dan menandakan lokasi tersebut berada pada lokasi yang strategis. Skoring peruntukan kawasan Sub BWP Perkotaan Cibinong Raya dapat dilihat pada Table 3 berikut:

Tabel 3. Skoring Sub BWP Perkotaan Cibinong Raya

\begin{tabular}{|c|c|c|c|}
\hline $\begin{array}{l}\text { Sub } \\
\text { BWP }\end{array}$ & Tema & Skor & Sumber \\
\hline PBR & $\begin{array}{l}\text { Transportasi dan } \\
\text { hunian vertikal }\end{array}$ & 1 & Akmal (2007) \\
\hline PKT & $\begin{array}{l}\text { Perdagangan dan } \\
\text { hunian vertikal }\end{array}$ & 1 & $\begin{array}{l}\text { Logan, dkk } \\
\text { (1999) }\end{array}$ \\
\hline GOR & $\begin{array}{l}\text { Sport city center } \\
\text { dan perkantoran }\end{array}$ & 2 & $\begin{array}{c}\text { Bappeda Kab. } \\
\text { Bogor }\end{array}$ \\
\hline LIPI & $\begin{array}{l}\text { Science center, } \\
\text { botanic garden }\end{array}$ & 3 & $\begin{array}{c}\text { Permen PU No } \\
41 / 2008\end{array}$ \\
\hline BOR & Kawasan industri & 3 & $\begin{array}{c}\text { Bappeda Kab. } \\
\text { Bogor }\end{array}$ \\
\hline $\mathrm{CDL}$ & $\begin{array}{l}\text { Hunian sedang dan } \\
\text { jasa komersil }\end{array}$ & 2 & $\begin{array}{c}\text { Bappeda Kab. } \\
\text { Bogor }\end{array}$ \\
\hline TOD & $\begin{array}{l}\text { Transportasi dan } \\
\text { mixed use }\end{array}$ & 1 & Akmal (2007) \\
\hline BJG & Hunian vertikal & 1 & $\begin{array}{c}\text { Bappeda Kab. } \\
\text { Bogor }\end{array}$ \\
\hline KRD & $\begin{array}{l}\text { Kawasan } \\
\text { pendidikan }\end{array}$ & 3 & $\begin{array}{c}\text { Bappeda Kab. } \\
\text { Bogor }\end{array}$ \\
\hline BMS & $\begin{array}{ll}\text { Industri } & \text { dan } \\
\text { pergudangan } & \\
\end{array}$ & 2 & $\begin{array}{c}\text { Bappeda Kab. } \\
\text { Bogor }\end{array}$ \\
\hline CRG & $\begin{array}{l}\text { Pusat pelayanan } \\
\text { kesehatan }\end{array}$ & 3 & $\begin{array}{c}\text { Bappeda Kab. } \\
\text { Bogor }\end{array}$ \\
\hline CTM & $\begin{array}{l}\text { Transportasi dan } \\
\text { hunian vertikal }\end{array}$ & 1 & Akmal (2007) \\
\hline PDKR & $\begin{array}{l}\text { Transportasi dan } \\
\text { hunian vertikal }\end{array}$ & 1 & Akmal (2007) \\
\hline SHT & Hunian sedang & 2 & $\begin{array}{c}\text { Bappeda Kab. } \\
\text { Bogor }\end{array}$ \\
\hline
\end{tabular}

Keterangan :
$1:$ Sesuai
2 : Kurang Sesuai
3 : Tidak Sesuai 
Properti apartemen memiliki karakteristik khusus dalam pemilihan lokasinya. Pemilihan Iokasi apartemen sangat mempertimbangkan waktu tempuh pencapaian dari lokasi apartemen menuju ke pusat aktivitas suatu kawasan perkotaan yang lamanya tidak lebih dari 15 (lima belas) menit (Fajar, dkk., 2016). Skoring jangkauan pencapaian ke pusat kota dapat dilihat pada Tabel 4 berikut:

Tabel 4. Skoring Jangkauan Pencapaian ke Pusat Kota

\begin{tabular}{ccc}
\hline Jangkauan Pencapaian & Skor & Sumber \\
\hline Kurang dari 15 menit & 1 & Fajar (2016) \\
\hline Lebih dari 15 menit & 2 & Fajar (2016) \\
Keterangan : & & \\
1 : Sesuai & & \\
2 : Tidak Sesuai & &
\end{tabular}

Hasil dari identifikasi dan skoring ketiga kriteria tersebut kemudian dijadikan bahan untuk analisis lokasi alternatif dengan metode weighted overlay.

Identifikasi Kriteria Pemilihan Lokasi Terbaik Pengembangan Properti Apartemen. Berdasarkan kajian literatur serta disesuaikan dengan kondisi dari lokasi penelitian, maka didapati struktur hirarki Analytical Hierarchy Process (AHP) pada penelitian ini sebagai berikut :

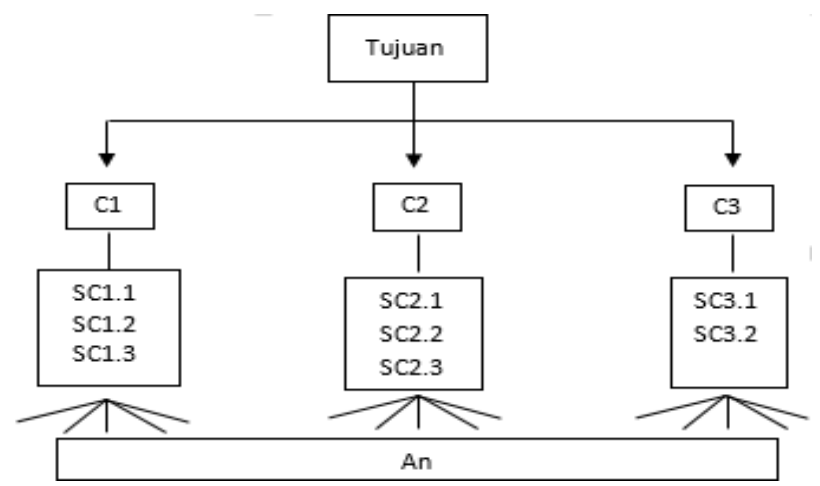

Gambar 1. Struktur Hirarki Analytical Hierarchy Process (AHP) dalam Penelitian

Tingkat I : Tujuan

Pemilihan lokasi terbaik pengembangan properti apartemen di Perkotaan Cibinong Raya

Tingkat II : Kriteria

Kriteria pada penelitian ini meliputi :

C1 : Aspek Fisik

C2 : Aspek Legalitas

C3 : Aspek Ekonomi
Tingkat III : Sub Kriteria

Sub kriteria pada penelitian ini meliputi :

SC1.1 : Aksesibilitas

SC1.2 : Moda transportasi

SC1.3 : Sarana dan prasarana

SC2.1 : Regulasi Penataan Ruang

SC2.2 : Status kepemilikan lahan

SC2.3 : Regulasi Bangunan Hunian Vertikal

SC3.1 : Harga lahan

SC3.2 : Pasar

Tingkat IV : Alternatif

Hasil dari weighted overlay berupa lokasi alternatif pengembangan properti apartemen di Perkotaan Cibinong Raya Kabupaten Bogor.

Analisis Lokasi Alternatif Pengembangan Properti Apartemen. Identifikasi kriteria lokasi alternatif pengembangan properti apartemen yang telah dilakukan sebelumnya menghasilkan skoring dari kriteria guna lahan eksisting, peruntukan kawasan Sub BWP Cibinong serta kriteria jangkauan pencapaian ke pusat kota. Skoring dari masingmasing kriteria tersebut kemudian menghasilkan peta reclassify dalam bentuk data shapefile, terhadap ketiga kriteria lokasi alternatif pengembangan properti apartemen yang dijadikan input dalam analisis weighted overlay (lihat Gambar 2).

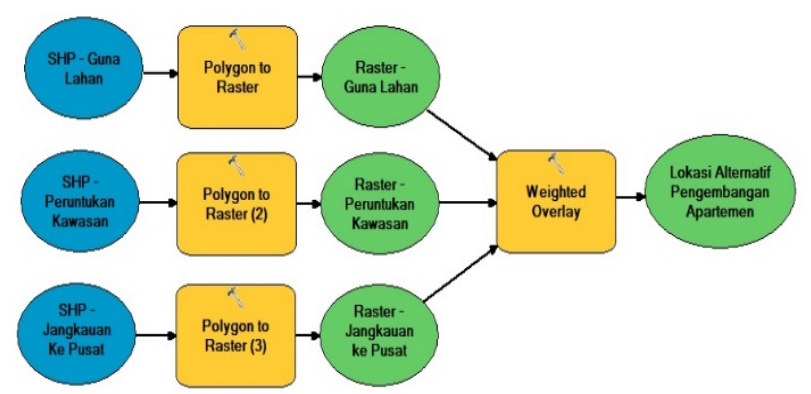

Gambar 2. Model Builder Weighted Overlay Pemilihan Lokasi Alternatif Pengembangan properti Apartemen

Adapun besaran percent of influences dari masingmasing kriteria, mendeskripsikan seberapa penting kriteria tersebut memberikan pengaruh dalam analisis weighted overlay ini. Berdasarkan wawancara dengan pihak Bappeda Kabupaten Bogor, percent of influences dari masing-masing kriteria dapat dilihat pada tabel 5 berikut: 
Tabel 5. Percent of Influences Kriteria pada Analisis Weighted Overlay

\begin{tabular}{lcc}
\hline \multicolumn{1}{c}{ Kriteria } & $\begin{array}{c}\text { Percent of } \\
\text { Influences }\end{array}$ & \multicolumn{1}{c}{ Sumber } \\
\hline Guna Lahan & $30 \%$ & Bappeda Kab. Bogor \\
\hline $\begin{array}{l}\text { Peruntukan } \\
\text { Kawasan BWP } \\
\text { Cibinong }\end{array}$ & $40 \%$ & Bappeda Kab. Bogor \\
\hline $\begin{array}{l}\text { Jangkauan } \\
\text { Pencapaian ke } \\
\text { Pusat Kota }\end{array}$ & $30 \%$ & Bappeda Kab. Bogor \\
\hline
\end{tabular}

Berdasarkan hasil analisis weighted overlay yang telah dilakukan (lihat Gambar 3a), terdapat beberapa lokasi yang memiliki kesesuaian untuk dijadikan lokasi alternatif pengembangan properti apartemen. Lokasi-lokasi yang sesuai tersebut, kemudian dilakukan seleksi dari segi luas lahan minimum dimana berdasarkan Fajar, dkk. (2016), syarat minimum luas lahan untuk pengembangan properti apartemen yaitu sebesar 1,5 $\mathrm{Ha}$. Terdapat empat lokasi alternatif pengembangan properti apartemen di Perkotaan Cibinong Raya Keempat lokasi alternatif tersebut kemudian disebut sebagai Lokasi A, Lokasi B, Lokasi C dan Lokasi D (lihat Gambar 3b). Lokasi A memiliki luas lahan sebesar 10,29 Ha. Lokasi B memiliki luas lahan 12,04 Ha. Sedangkan untuk dua lokasi lainnya yaitu Lokasi $\mathrm{C}$ dan Lokasi D masing-masing memiliki luas lahan sebesar 12,48 Ha dan 7,25 Ha. Keempat lokasi alternatif tersebut selain layak berdasarkan skoring dengan analisis weighted overlay, juga layak berdasarkan luas lahan dimana luas lahan minimum suatu lokasi apartemen yaitu 1,5 ha. Selanjutnya, keempat lokasi alternatif tersebut akan dilakukan penilaian oleh para responden berdasarkan delapan sub kriteria lokasi terbaik pengembangan properti apartemen dengan menggunakan metode Analytical Hierarchy Process (AHP).

Penentuan Prioritas Kriteria. Penentuan prioritas kriteria bertujuan untuk mengetahui kriteria yang paling berpengaruh dalam pemilihan lokasi terbaik pengembangan properti apartemen.

Berdasarkan hasil penilaian prioritas kriteria (lihat tabel 6), kriteria legalitas merupakan kriteria yang memiliki bobot penilaian tertinggi menurut persepsi dari para responden dengan nilai 0,556, mengungguli kedua kriteria lainnya yaitu fisik dan ekonomi dengan besaran nilai masing-masing sebesar 0,28 dan 0,177 . Perbedaan yang cukup signifikan antara besaran nilai pembobotan yang diperoleh kriteria legalitas dibandingkan dengan kriteria lainnya, mencerminkan kriteria legalitas menjadi prioritas utama sebagai kriteria yang dipertimbangkan dan memberikan pengaruh terbesar dalam pemilihan lokasi terbaik pengembangan properti apartemen.

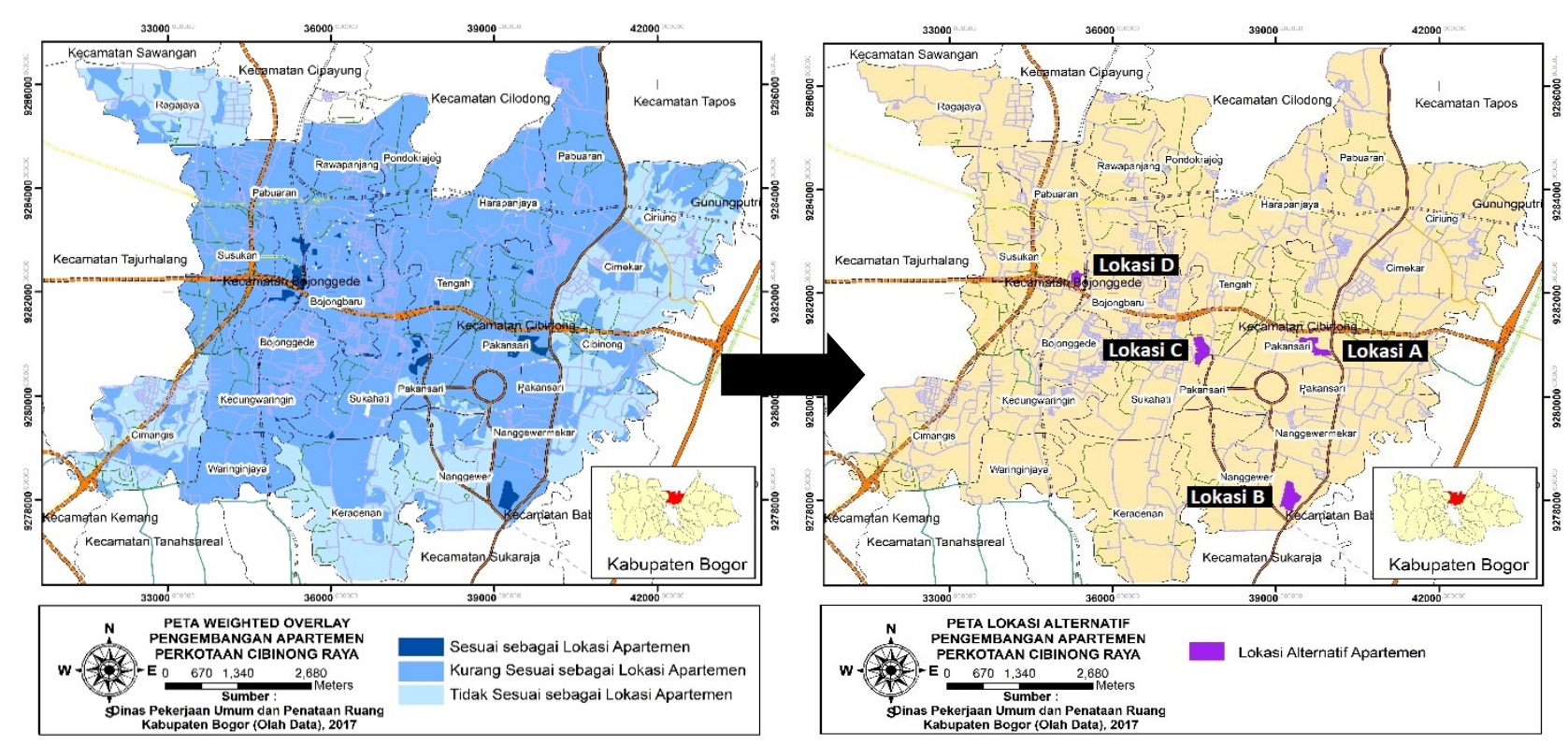

Gambar 3. (A) Peta Weighted Overlay. (B) Peta Lokasi Alternatif Pengembangan Properti Apartemen di Perkotaan Cibinong Raya. 
Tabel 6. Penentuan Prioritas Kriteria Lokasi Terbaik Apartemen

\begin{tabular}{lcccc}
\hline \multicolumn{1}{c}{ Responden } & Fisik & Legalitas & Ekonomi & IK $^{*}$ \\
\hline $\begin{array}{l}\text { Bappeda Kab. } \\
\text { Bogor }\end{array}$ & 0,14 & 0,528 & 0,333 & 0,05 \\
\hline $\begin{array}{l}\text { Dinas PUPR } \\
\text { Kab. Bogor }\end{array}$ & 0,279 & 0,649 & 0,072 & 0,06 \\
\hline $\begin{array}{l}\text { Dinas PKPP } \\
\text { Kab. Bogor }\end{array}$ & 0,218 & 0,691 & 0,091 & 0,05 \\
\hline $\begin{array}{l}\text { PT. Riscon } \\
\text { Victory }\end{array}$ & 0,443 & 0,387 & 0,169 & 0,02 \\
\hline $\begin{array}{l}\text { PT. Raffah } \\
\text { Alam Persada }\end{array}$ & 0,16 & 0,691 & 0,149 & 0,01 \\
\hline $\begin{array}{l}\text { PT. Karya } \\
\text { Raharja }\end{array}$ & 0,444 & 0,111 & 0,444 & 0,00 \\
Sejahtera & 0,188 & 0,731 & 0,081 & 0,06 \\
\hline Dosen PWK I & 0,079 & 0,03 \\
\hline Dosen PWK II & 0,263 & 0,659 & 0,079 & 0,03 \\
\hline Rata-rata & $\mathbf{0 , 2 6 7}$ & $\mathbf{0 , 5 5 6}$ & $\mathbf{0 , 1 7 7}$ & $\mathbf{0}$ \\
\hline Keterangan: $:$ Indeks Konsistensi & &
\end{tabular}

Keterangan : ${ }^{*}$ ) : Indeks Konsistensi

Prioritas selanjutnya ditempati oleh kriteria fisik Dalam pemilihan lokasi terbaik pengembangan properti apartemen, tentunya juga harus mempertimbangkan kondisi fisik eksisting maupun rencana pengembangan fisik dari suatu kawasan seperti aksesibilitas, moda transportasi serta sarana dan prasarana. Sehingga mayoritas responden menilai kriteria fisik merupakan kriteria yang cukup penting dalam pemilihan lokasi terbaik pengembangan properti apartemen.

Kriteria ekonomi merupakan kriteria yang berada pada prioritas terakhir pada penilaian prioritas kriteria ini. Sebagian besar responden beranggapan, kriteria ekonomi merupakan implikasi dari kriteria legalitas dan kriteria fisik. Apabila kedua kriteria lainnya memiliki penilaian yang baik pada suatu lokasi alternatif pengembangan properti apartemen, maka kriteria ekonomi yang terdiri dari harga lahan dan pasar pun juga memiliki nilai yang baik. Oleh karena itu, sebagian besar para responden menilai kriteria ekonomi tidak terlalu memberikan pengaruh dalam pemilihan lokasi terbaik pengembangan properti apartemen dibandingkan kedua kriteria lainnya.

Penentuan Prioritas Sub Kriteria. Penentuan prioritas sub kriteria bertujuan untuk mengetahui sub kriteria yang memiliki pengaruh paling besar pada tiap-tiap kriteria lokasi terbaik pengembangan properti apartemen.

Kriteria fisik memiliki 3 (tiga) sub kriteria yaitu sub kriteria aksesibilitas (SC 1.1), sub kriteria moda transportasi (SC 1.2) dan sub kriteria sarana dan prasarana (SC 1.3). Sub kriteria aksesibilitas terkait dengan jaringan jalan, jarak ke pusat kota serta rencana pengembangan aksesibilitas di masa yang akan datang. Sub kriteria moda transportasi terkait dengan ketersediaan dan keterjangkauan lokasi pengembangan properti apartemen dari moda transportasi. Sedangkan sub kriteria sarana dan prasarana terkait dengan ketersediaan sarana dan prasarana penunjang seperti sarana pendidikan, kesehatan, dan fasilitas umum di sekiar lokasi pengembangan properti apartemen dalam pemenuhan kebutuhan dari pengguna apartemen.

Kriteria legalitas terdiri dari 3 (tiga) sub kriteria yang berkaitan dengan regulasi-regulasi pengembangan properti apartemen. Ketiga sub kriteria legalitas tersebut yaitu sub kriteria regulasi penataan ruang (SC. 2.1), sub kriteria kepemilikan lahan (SC. 2.2) dan sub kriteria regulasi hunian vertikal (SC 2.3). Sub kriteria regulasi penataan ruang terkait dengan regulasi dari perencanaan dan penataan ruang yang terdapat pada dokumen Rencana Tata Ruang Wilayah (RTRW) dan dokumen Rencana Detil Tata Ruang (RDTR). Sub kriteria kepemilikan lahan terkait dengan hak penggunaan dan pemanfaatan dari suatu bidang lahan. Sedangkan sub kriteria regulasi hunian vertikal terkait dengan regulasi teknis pembangunan hunian vertikal diantaranya koefisien dasar bangunan dan ketinggian bangunan.

Kriteria ekonomi terdiri dari 2 (dua) sub kriteria yaitu sub kriteria harga lahan dan sub kriteria pasar. Sub kriteria harga lahan terkait besaran harga lahan berdasarkan Nilai Jual Objek Pajak (NJOP). Sedangkan sub kriteria pasar terkait dengan keberadaan kompetitor sejenis yang turut mengembangkan bisnis properti apartemen. Hasil penentuan prioritas sub kriteria, dapat dilihat pada Tabel 7 berikut : 
Tabel 7. Penentuan Prioritas Sub Kriteria Lokasi Terbaik Pengembangan Properti Apartemen

\begin{tabular}{|c|c|c|c|c|c|c|c|c|c|c|}
\hline \multirow[t]{2}{*}{ Responden } & \multicolumn{4}{|c|}{ Sub Kriteria Fisik } & \multicolumn{4}{|c|}{ Sub Kriteria Legalitas } & \multicolumn{2}{|c|}{$\begin{array}{c}\text { Sub Kriteria } \\
\text { Ekonomi }\end{array}$} \\
\hline & SC1.1 & SC1.2 & SC1.3 & IK *) & SC2.1 & SC2.2 & SC2.3 & IK *) & SC 3.1 & SC 3.2 \\
\hline Bappeda Kab. Bogor & 0,279 & 0,649 & 0,072 & 0,06 & 0,143 & 0,714 & 0,143 & 0,00 & 0,8 & 0,2 \\
\hline Dinas PUPR Kab. Bogor & 0,229 & 0,075 & 0,696 & 0,07 & 0,433 & 0,1 & 0,466 & 0,01 & 0,167 & 0,833 \\
\hline Dinas PKPP Kab. Bogor & 0,733 & 0,068 & 0,199 & 0,09 & 0,796 & 0,079 & 0,125 & 0,05 & 0,5 & 0,5 \\
\hline PT. Riscon Victory & 0,416 & 0,458 & 0,126 & 0,01 & 0,096 & 0,799 & 0,105 & 0,01 & 0,833 & 0,167 \\
\hline PT. Raffah Alam Persada & 0,644 & 0,271 & 0,085 & 0,05 & 0,143 & 0,714 & 0,143 & 0,00 & 0,25 & 0,75 \\
\hline PT. Karya Raharja Sejahtera & 0,429 & 0,429 & 0,143 & 0,00 & 0,155 & 0,71 & 0,135 & 0,02 & 0,5 & 0,5 \\
\hline Dosen PWK I & 0,637 & 0,258 & 0,105 & 0,04 & 0,515 & 0,097 & 0,388 & 0,04 & 0,833 & 0,167 \\
\hline Dosen PWK II & 0,250 & 0,655 & 0,095 & 0,02 & 0,258 & 0,105 & 0,637 & 0,04 & 0,25 & 0,75 \\
\hline Rata-rata & 0,452 & 0,358 & 0,190 & 0,04 & 0,317 & 0,415 & 0,268 & 0,021 & 0,517 & 0,483 \\
\hline
\end{tabular}

Keterangan : *) Indeks Konsisten

Hasil penilaian penentuan prioritas sub kriteria fisik (lihat Tabel 7), dapat diketahui bahwa mayoritas para responden memilih aksesibilitas sebagai prioritas tertinggi pada sub kriteria fisik dengan bobot sebesar 0,452 dibandingkan dengan sub kriteria fisik lainnya yaitu moda transportasi dan sarana dan prasarana dengan nilai masing-masing sebesar 0,358 dan 0,190. Pemilihan aksesibilitas sebagai prioritas tertinggi pada sub kriteria fisik ini dikarenakan aksesibilitas memegang peranan penting dalam pemilihan lokasi terbaik serta berperan dalam pengembangan suatu kawasan. Selain itu, aksesibilitas juga dianggap sebagai dasar untuk pengembangan moda transportasi serta sarana dan prasarana. Sehingga aksesibilitas menjadi prioritas utama dalam penentuan prioritas sub kriteria fisik.

Pada penilaian penentuan prioritas sub kriteria legalitas (lihat Tabel 7), diketahui status kepemilikan lahan memiliki nilai paling tinggi diantara kedua sub kriteria legalitas lainnya yaitu regulasi penataan ruang dan regulasi hunian vertikal. Status kepemilikan lahan mendapatkan nilai sebesar 0,415 , unggul tipis dari regulasi penataan ruang dengan nilai bobot 0,317 dan unggul cukup telak dari regulasi hunian vertikal dengan nilai bobot 0,268 . Hasil dari penilaian tersebut mencerminkan bahwa, dari sisi legalitas aspek kepemilikan lahan sebagai prioritas utama yang perlu dipertimbangkan dalam pemilihan lokasi terbaik pengembangan properti apartemen. Status kepemilikan lahan terkait legalitas dari lahan itu sendiri seperti hak atas pemanfaatan dari lahan tersebut.

Sedangkan hasil penilaian prioritas sub kriteria ekonomi (lihat Tabel 7), dapat diketahui mayoritas responden memilih harga lahan sebagai sub kriteria ekonomi paling berpengaruh dengan nilai 0,517 unggul tipis dari sub kriteria ekonomi pasar dengan nilai 0,483 . Meskipun kedua sub kriteria ekonomi tersebut memiliki selisih yang cukup kecil, namun para responden beranggapan harga lahan menjadi faktor yang paling dipertimbangkan dari sisi ekonomi dalam hal pemilihan lokasi terbaik pengembangan properti apartemen.

Kecenderungan ini didorong oleh persepsi dari mayoritas responden yang menganggap harga lahan identik dengan besaran biaya modal yang harus diinvestasikan oleh suatu pengembang yang kemudian harus dapat ditutupi melalui penjualan produk properti. Sedangkan pasar yang berkaitan dengan keberadaan kompetitor properti apartemen sejenis, merupakan suatu fenomena yang dianggap wajar dimana semakin meningkatnya nilai kestrategisan dari suatu lokasi lahan akan diikuti oleh meningkatnya jumlah dari keberadaan kompetitor sejenis yang turut mengembangkan produk properti apartemen.

Analisis Lokasi Terbaik Pengembangan Properti Apartemen. Analisis weighted overlay yang telah dilakukan sebelumnya menghasilkan empat lokasi yang sesuai untuk dikembangkan sebagai lokasi 
alternatif pengembangan properti apartemen. Keempat lokasi alternatif tersebut kemudian dinilai oleh para responden berdasarkan delapan sub kriteria lokasi terbaik pengembangan properti apartemen dengan menggunakan metode Analytical Hierarchy Process (AHP). Hasil penilaian tersebut, dapat dilihat pada Tabel 8 berikut:

Tabel 8. Penilaian Lokasi Terbaik Pengembangan Apartemen

\begin{tabular}{|c|c|c|c|c|}
\hline \multirow{2}{*}{ Sub kriteria } & \multicolumn{4}{|c|}{ Lokasi Alternatif } \\
\hline & $\mathbf{A}$ & B & C & D \\
\hline Kriteria Fisik & 0.352 & 0.169 & $\begin{array}{c}0.18 \\
9\end{array}$ & 0.287 \\
\hline Aksesibilitas & 0.331 & 0.241 & $\begin{array}{c}0.21 \\
6 \\
\end{array}$ & 0.205 \\
\hline Moda Transportasi & 0.319 & 0.161 & 0.14 & 0.38 \\
\hline Sarana Prasarana & 0.406 & 0.106 & $\begin{array}{c}0.21 \\
3\end{array}$ & 0.276 \\
\hline Kriteria Legalitas & 0.34 & 0.12 & $\begin{array}{c}0.20 \\
7\end{array}$ & 0.34 \\
\hline $\begin{array}{l}\text { Regulasi Penataan } \\
\text { Ruang }\end{array}$ & 0.366 & 0.072 & $\begin{array}{c}0.12 \\
4\end{array}$ & 0.438 \\
\hline Kepemilikan Lahan & 0.279 & 0.162 & $\begin{array}{c}0.33 \\
4\end{array}$ & 0.225 \\
\hline $\begin{array}{l}\text { Regulasi Hunian } \\
\text { Vertikal }\end{array}$ & 0.375 & 0.127 & $\begin{array}{c}0.16 \\
3 \\
\end{array}$ & 0.358 \\
\hline Kriteria Ekonomi & 0.197 & 0.122 & $\begin{array}{c}0.27 \\
9 \\
\end{array}$ & 0.402 \\
\hline Harga Lahan & 0.129 & 0.082 & $\begin{array}{c}0.35 \\
2 \\
\end{array}$ & 0.437 \\
\hline Pasar & 0.265 & 0.162 & $\begin{array}{c}0.20 \\
7\end{array}$ & 0.367 \\
\hline Total Rata-rata & 0.309 & 0.139 & $\begin{array}{c}0.21 \\
8 \\
\end{array}$ & 0.336 \\
\hline Peringkat Lokasi & II & IV & III & I \\
\hline
\end{tabular}

Berdasarkan hasil penilaian oleh para responden terhadap empat lokasi alternatif pengembangan properti apartemen (lihat Tabel 8). Lokasi D sebagai lokasi dengan bobot nilai tertinggi sebesar 0,336. Kemudian disusul oleh Lokasi A dengan bobot 0,309 , serta Lokasi $C$ dan Lokasi $B$ dengan masingmasing bobot sebesar 0,218 dan 0,139.

Berdasarkan karakteristik masing-masing lokasi, peilihan lokasi $\mathrm{D}$ sebagai lokasi terbaik untuk lokasi apartemen di Cibinong Raya dipengaruhi oleh keunggulan yang dimilikinya, terutama terkait dengan kriteria legalitas dan ekonomi. Mengacu pada Rencana Detil Tata Ruang Sub BWP Perkotaan Cibinong Raya, Lokasi D akan dikembangkan sebagai kawasan pusat transportasi dengan konsep
Transit Oriented Development serta Mixed Use Building. Harga lahan di Lokasi D juga cenderung lebih murah dibandingkan lokasi lainnya dimana besaran harga lahan di Lokasi $\mathrm{D}$ dikisaran harga $\mathrm{Rp}$. 1.000.000 - Rp. 2.000.000 per meter perseginya. Selain keunggulan pada kedua hal tersebut, Lokasi $D$ juga memiliki keunggulan dalam hal sub kriteria moda transportasi. Terdapat jaringan serta stasiun kereta commuterline yang berlokasi dekat dengan Lokasi $D$ sehingga Lokasi $D$ memiliki keberagaman dari moda transportasi umum dibandingkan dengan lokasi alternatif lainnya.

\section{KESIMPULAN}

Berdasarkan analisis weighted overlay terhadap kriteria lokasi alternatif pengembangan properti apartemen yang terdiri dari guna lahan, peruntukan kawasan dan jangkauan pencapaian, dihasilkan empat lokasi alternatif (Lokasi A, Lokasi B, Lokasi C dan Lokasi D) yang sesuai untuk dikembangkan sebagai lokasi properti apartemen. Keempat lokasi alternatif hasil dari weighted overlay tersebut, kemudian dilakukan penilaian oleh para responden dengan menggunakan metode AHP berdasarkan 8 (delapan) sub kriteria pemilihan lokasi terbaik pengembangan properti apartemen yang terdiri dari sub kriteria fisik yaitu aksesibilitas, moda transportasi, sarana dan prasarana, sub kriteria legalitas yaitu regulasi penataan ruang, kepemilikan lahan dan regulasi hunian vertikal, serta sub kriteria ekonomi terkait dengan harga lahan dan pasar. Berdasarkan penilaian oleh para responden, Lokasi D terpilih sebagai lokasi terbaik pengembangan properti apartemen di perkotaan Cibinong Raya dengan bobot sebesar 0,336 disusul secara berturut-turut oleh Lokasi A, Lokasi C dan Lokasi B dengan masing-masing nilai sebesar 0,309, 0,218, dan 0,139.

Temuan pada penelitian ini yaitu adanya pengembangan properti apartemen yang dilakukan diluar dari keempat lokasi alternatif pengembangan properti apartemen berdasarkan hasil penelitian ini. Pada dasarnya, pengembangan lokasi apartemen diluar dari lokasi alternatif hasil penelitian ini diperbolehkan dan dapat dilakukan. Namun, yang cukup disayangkan terdapat beberapa lokasi pengembangan properti apartemen di 
Perkotaan Cibinong Raya saat ini, dikembangkan pada lokasi dengan kondisi aksesibilitas yang relatif sempit dan terbatas serta memiliki luas lahan kurang dari standar minimum luas lahan sebuah apartemen yaitu 1,5 ha. Kondisi seperti ini tentunya tidak sesuai dengan kaidah-kaidah teoritis pemilihan lokasi terbaik pengembangan properti apartemen dimana suatu lokasi pengembangan properti apartemen harus memiliki luas lahan lebih dari 1,5 Ha (Fajar, dkk., 2016).

Selain itu temuan penelitian lainnya, terdapat perbedaan antara hasil dari penelitian dengan kondisi di lapangan saat ini dari segi nilai lokasi terbaik pengembangan properti apartemen. Pengembang cenderung memilih lokasi di sekitar koridor Jalan Raya Bogor sebagai lokasi terbaik pengembangan properti apartemen. Hal ini tentunya memiliki perbedaan dimana Lokasi B yang berlokasi di sekitar Jalan Raya Bogor justru sebagai lokasi alternatif dengan bobot nilai terendah berdasarkan penilaian lokasi terbaik pengembangan properti apartemen pada penelitian ini. Adanya fenomena perbedaan antara hasil dari penelitian ini baik berupa jumlah lokasi alternatif maupun penilaian terhadap lokasi terbaik pengembangan properti apartemen, dengan kondisi di lapangan saat ini dapat disebabkan oleh berbagai macam faktor seperti strategi bisnis dan pengembangan yang dilakukan oleh internal pihak pengembang properti apartemen tersebut, maupun dapat disebabkan oleh perbedaan kriteria dalam penilaian lokasi terbaik pengembangan properti apartemen.

Oleh karena itu, berdasarkan temuan penelitian diatas, terdapat beberapa rekomendasi yang dapat dilakukan oleh akademisi bidang perencanaan wilayah dan kota, pengembang properti maupun pemerintah terkait dengan penelitian ini. Pertama, penelitian ini dapat dijadikan lesson learned bagi para akademisi bidang perencanaan wilayah dan kota bahwa dalam penelitian suatu lokasi terbaik pengembangan properti apartemen tidak bisa dengan cara hanya mengacu pada suatu ketentuan formal saja seperti teori-teori dan kaidah-kaidah perencanaan akan tetapi juga dapat mempertimbangkan dari sisi non formal seperti fenomena-fenomena yang berkembang di lapangan. Pihak akademisi juga dapat melakukan pengembagan penelitian ini dengan memasukan lebih banyak kriteria-kriteria lokasi terbaik pengembangan properti apartemen, mengkaji jenis properti apartemen yang sesuai dan highest and best use, maupun pengembangan penelitian dari segi perencanaan dan perancangan apartemen itu sendiri seperti perencanaan bentuk dan ukuran bangunan serta siteplan dari kawasan apartemen pada masing-masing lokasi alternatif hasil dari penelitian ini.

Kedua, pihak pengembang dapat menjadikan hasil penelitian ini sebagai bahan rujukan dan rekomendasi dalam pemilihan lokasi pengembangan properti apartemen, baik dari segi lokasinya maupun dari segi kriteria-kriteria penilaian dalam pemilihan suatu lokasi terbaik pengembangan properti apartemen. Selain itu, dalam pelaksanaan pengembangan properti apartemen, pihak pengembang juga hendaknya tidak berorientasi pada keuntungan secara finansial saja. Pengembang juga harus memperhatikan kaidah-kaidah perencanaan properti apartemen agar menghasilkan suatu produk properti apartemen yang bernilai optimum baik dari segi finansial ekonomi maupun dari sisi fisik dan legalitas sehingga pengembangan properti apartemen ini dapat menjadi solusi dari pemenuhan hunian tempat tinggal di tengah keterbatasan lahan perkotaan saat ini.

Ketiga, pemerintah dapat menjadikan hasil penelitian sebagai rujukan tambahan dalam penentuan zonasi-zonasi untuk pengembangan hunian vertikal seperti apartemen. Sebagai pemangku kebijakan, pemerintah juga dapat memberikan intensif dan sanksi kepada pihak-pihak developer yang taat dan melanggar regulasi yang telah ditetapkan oleh pemerintah.

\section{DAFTAR PUSTAKA}

Akmal, I. (2007). Menata apartemen: Gramedia Pustaka Utama.

Al-Ossmi, L. H., \& Ahmed, V. (2016). Land tenure administration: Towards a regulatory backdrop to land tenure in Iraq. Land use policy, 57, 250264.

Appraisal Institute. (2001). The appraisal of real estate: Appraisal Institute, US. 
Bappeda Kabupaten Bogor. (2016). Rencana Tata Ruang dan Wilayah Kabupaten Bogor Tahun 20112031.

Chang, K.-L., Liao, S.-K., Tseng, T.-W., \& Liao, C.-Y. (2015). An ANP based TOPSIS approach for Taiwanese service apartment location selection. Asia Pacific Management Review, 20(2), 49-55.

Chavunduka, C. M., \& Bromley, D. W. (2013). Considering the multiple purposes of land in Zimbabwe's economic recovery. Land use policy, 30(1), 670676.

Du, H., Ma, Y., \& An, Y. (2011). The impact of land policy on the relation between housing and land prices: Evidence from China. The Quarterly Review of Economics and Finance, 51(1), 19-27.

Fajar, A. A., Sarjono, B. A., \& Iswanto, D. (2016). Apartemen di Kawasan Intermoda BSD Tangerang. (Tugas Akhir), Universitas Diponegoro.

Hirsch, W. Z. (1977). The efficiency of restrictive land use instruments. Land Economics, 53(2), 145-156.

Karana, R. C., \& Suprihardjo, R. (2013). Mitigasi Bencana Banjir Rob di Jakarta Utara. Jurnal Teknik ITS, 2(1), C31-C36.

Kheir, N., \& Portnov, B. A. (2016). Economic, demographic and environmental factors affecting urban land prices in the Arab sector in Israel. Land use policy, 50, 518-527.

Koester. (2001). Tapak Keruangan Perkotaan. Jakarta: Penerbit UI Press.

Kombaitan, B. (1995). Perijinan Pembangunan Kawasan dalam Penataan Ruang. Journal of Regional and City Planning, 6(17), 17-24.

Kuswara. (2004). Penataan Sistem Perumahan dan Permukiman dalam Rangka Gerakan Nasional Pengembangan Satu Juta Rumah. Jurnal Penelitian Permukiman, 20, 23-29.
Logan, J. R., Bian, Y., \& Bian, F. (1999). Housing inequality in urban China in the 1990s. International Journal of Urban and Regional Research, 23(1), 7-25.

Magliocca, N., McConnell, V., Walls, M., \& Safirova, E. (2012). Zoning on the urban fringe: Results from a new approach to modeling land and housing markets. Regional Science and Urban Economics, 42(1), 198-210.

Morrow-Jones, H. A., Irwin, E. G., \& Roe, B. (2004). Consumer preference for neotraditional neighborhood characteristics. Housing Policy Debate, 15(1), 171-202.

Nugraha, Y. K., Nugraha, A. L., \& Wijaya, A. P. (2014). Pemanfaatan Sig Untuk Menentukan Lokasi Potensial Pengembangan Kawasan Perumahan Dan Permukiman (Studi Kasus Kabupaten Boyolali). Jurnal Geodesi Undip, 3(4), 50-59.

Pontoh, N. K., \& Kustiwan, I. (2009). Pengantar Perencanaan Perkotaan. Bandung: Penerbit ITB.

Qian, Z. (2010). Without zoning: Urban development and land use controls in Houston. Cities, 27(1), 3141.

Saaty, T. L. (1993). Pengambilan keputusan bagi para pemimpin. PT Pustaka Binaman Pressindo. Jakarta.

Sadyohutomo, M. (2008). Manajemen kota dan wilayah: realita \& tantangan: Bumi Aksara.

Sugiyono. (2014). Metode Penelitian Kuantitatif, Kualitatif, dan R\&D. Bandung: Alfabeta.

Winarso, H., \& Firman, T. (2002). Residential land development in Jabotabek, Indonesia: triggering economic crisis? Habitat International, 26(4), 487-506. 